\title{
The activity of $\beta$-glucosidase and guaiacol peroxidase in different genotypes of winter oilseed rape (Brassica napus L.) infected by Alternaria black spot fungi
}

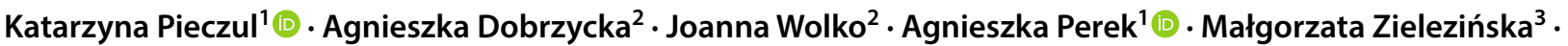 \\ Jan Bocianowski ${ }^{4} \cdot$ Magdalena Rybus-Zając $^{3}$
}

Received: 14 May 2019 / Revised: 2 July 2020 / Accepted: 13 July 2020 / Published online: 31 July 2020

(c) The Author(s) 2020

\begin{abstract}
The plants have developed several defense mechanisms to counteract pathogens. Among others, it includes activation of antioxidant enzymes like $\beta$-glucosidase and guaiacol peroxidase (GPX). These proteins participate in the oxidation of phenolic compounds, contributing to their increased fungitoxicity. The study aimed to analyze changes in the activity of $\beta$-glucosidase and GPX in four genotypes of winter oilseed rape (Mendel, Monolit, Polka, line L1425) inoculated with seven isolates: Alternaria brassicicola, Alternaria brassicae, Alternaria alternata (3 strains), Ulocladium chartarum (syn. A. chartarum), and Cladosporium cladosporioides. We noted that the varieties of oilseed rape, tested fungal species, and time of the plant material collection had significant $(P<0.001)$ effect on the activity of $\beta$-glucosidase and GPX per protein and fresh matter content comparing to the control group. A. brassicicola caused the highest mean increase in $\beta$-glucosidase and GPX activity in all examined genotypes, while other pathogens had a lower impact. Significantly lower $\beta$-glucosidase activity inoculated by various pathogens was noted between the L 1425 line and other varieties. GPX activity was in the opposite, the lowest activity was recorded in the Mendel variety, and the highest in the L 1425 line.
\end{abstract}

Keywords Oilseed rape $\cdot \beta$-glucosidase $\cdot$ Guaiacol peroxidase $\cdot$ Alternaria black spot

\section{Introduction}

Currently, a significant threat to rapeseed is Alternaria black spot. The infection significantly reduces the area of photosynthesis and accelerates senescence of the plant, and negatively affects the proper development and quality of seeds,

Communicated by M. Horbowicz.

Katarzyna Pieczul

k.pieczul@iorpib.poznan.pl

1 Institute of Plant Protection, National Research Institute, Węgorka 20, 60-318 Poznań, Poland

2 Poznań Research Center, Plant Breeding and Acclimatization Institute, National Research Institute, Strzeszyńska 36, 60-479 Poznań, Poland

3 Department of Plant Physiology, Poznań University of Life Sciences, Wołyńska 35, 60-637 Poznań, Poland

4 Department of Mathematical and Statistical Methods, Poznań University of Life Sciences, Wojska Polskiego 28, 60-637 Poznań, Poland its weight, color, and oil content (Kumar et al. 2014; Meena et al. 2010). The intensification of the disease occurrence is affected mostly by weather conditions, such as the amount and distribution of rainfall, temperature, and relative humidity of the air (Koch et al. 2007). In the conditions favorable for pathogens development, crop losses can reach up to several tens of percent (Koch et al. 2007). The intensity of Alternaria infection also depends on the rapeseed variety (El-Beltagi et al. 2011; Kumar et al. 2014). In Poland, the most common Alternaria black spot pathogens are A. brassicae, A. alternata, and A. brassicicola (Jajor and Korbas 2012). Many Alternaria species produce mycotoxins, important in the pathogenesis of plants. They can act by direct damage to plant tissue or by inducing programmed cell death (Logreico et al. 2009). The disease is often accompanied by other saprotrophic species re-inhabiting plant tissues like Ulocladium, Embellisia, and Cladosporium (Perek et al. 2017). However, their significance for the development of Alternaria black spot was not explained definitively.

Plants have developed different defense mechanisms to counter the attack of pathogens. The passive defense is based 
on the presence of structural barriers or anti-microbial factors preventing infection of plant tissues. In active protection, many enzymatic pathways are involved (Pandey et al. 2017). It includes activation of defense enzymes such as $\beta$-glucosidase or guaiacol peroxidase (GPX) (Prasannath 2017). These natural plant protection processes have an essential role in the crop plant defense to pathogens, in addition to varieties with genetically induced resistance.

In plants, $\beta$-glucosidases are involved in many physiological processes. Among others, they are responsible for the formation of intermediates in cell wall lignification, cell wall degradation, activation of phytohormones, biotic and abiotic stress response or stimulation of defense compounds (Ashraf and Ali 2008; Halkier and Gershenzon 2006; Ketudat Cairns and Esen 2010; Lee et al. 2006). In the infection response, $\beta$-glucosidases are involved in the release of glucose from oligosaccharides, hydrolysis of glucosinolates, cell wall catabolism, activation of lignin precursors, the release of phytohormones or toxic compounds, such as aldehydes or ketones (Ketudat Cairns and Esen 2010; Moller 2010; Morant et al. 2008; Rask et al. 2000; Rojas et al. 2018; Sherameti et al. 2008).

The plant peroxidases are associated with many biosynthetic processes of plant growth, including cell wall metabolism, lignification, fruit growth and ripening, seed germination, and defense against abiotic and biotic stresses. (Passardi et al. 2005). These stress factors include different pollutants, salt, herbicides, ozone, or pathogen pressure (Heidari 2010; Sharma et al. 2012). GPX is involved in removing excess reactive oxygen species such as hydrogen peroxide $\left(\mathrm{H}_{2} \mathrm{O}_{2}\right)$ and can lower the free radical generation and neutralize excess free radicals created by stress conditions (El-Beltagi et al. 2011). Moreover, it participates in the oxidation of phenolic compounds, contributing to their increased fungitoxicity. Thus it generates metabolites for the synthesis of structural barriers: lignins, melanins, feruloylated polysaccharides, and glycoproteins, etc. limiting the spread of pathogenic microorganisms in plants (Beckman 2000; Vance and Kirk 1980).

To date, the influence of infection with fungal pathogens on the activities of $\beta$-glucosidase or GPX occurring in various rapeseed varieties has not been considered enough. The study aimed to analyze changes in the activity of $\beta$-glucosidase and GPX in different varieties of winter oilseed rape inoculated with pathogens causing Alternaria black spot-A. brassicicola, A. brassicae, A. alternata, as well as Ulocladium chararum, and Cladosporium cladosporioides.

\section{Materials and methods}

\section{Plant material}

For the study, four winter oilseed rape varieties: Monolit, Mendel, Polka, and a yellow-seeded line L 1425 were used. Monolit is the most common open-pollinated cultivar in Poland. It is characterized as cold-resistant, high seed yield, and high oil content. Mendel is the first Polish hybrid variety with confirmed resistance to basic types of clubroot. Polka is a new open-pollinated variety included in the Polish National List of Varieties in 2016, characterized by a modified fatty acid composition ratio (over $70 \%$ of oleic acid and a reduced content of linoleic acid). Line 1425 is a yellow-seeded line, with higher oil and protein content and lower fiber content in seeds in comparison to black-seeded genotypes.

\section{Fungal isolates}

In the study, Alternaria brassicicola, Alternaria brassicae, Alternaria alternata (three genetically different isolates), Ulocladium chartarum (syn. A. chartarum), and Cladosporium cladosporioides were tested. The fungal cultures were isolated in 2016 from infected oilseed rape plants derived from fields located in the region of Greater Poland (Wielkopolska). Species of tested isolates were identified based on macro- and microscopic morphological features of the colonies (Simmons 2007). Morphological identification was confirmed by sequence analysis of ribosomal DNA (ITS1-5.8SrDNA-ITS2).

All tested isolates were spiked on PDA (potato dextrose agar) or PCA (potato carrot agar) medium in Petri dishes. The colonies were incubated at room temperature (20-24 ${ }^{\circ} \mathrm{C}$ ) for 2 weeks. Then spores were collected from the surface of the medium and made into inoculum slurry.

\section{Greenhouse experiment}

Each genotype of rapeseed was sown in 72 pots $\left(280 \mathrm{~cm}^{3}\right)$ filled with Kronen gardening soil (pH 6.0-6.8). Ten seeds were sown in each pot to obtain five plants per pot as a result. The containers were placed in the greenhouse at 26-28/14-16 ${ }^{\circ} \mathrm{C}$ (day/night) with natural light and watered by the accepted practice for the species. After 32 days, the plants were inoculated by spraying the upper surface of leaves by different pathogen spores: A. brassicicola (A), A. brasicae (B), three genetically different isolates of $A$. alternata-C, E, G (based on ITS1-5.8SrDNA-ITS2 sequence analysis), $U$. chartarum (D), C. cladosporioides (F). The spore concentration was determined with the Thoma cell 
counting chamber and standardized to $0.5 \times 10^{6} / \mathrm{ml}$, except for $C$. cladosporioides which concentration was $2 \times 10^{6} / \mathrm{ml}$. Each inoculum in the amount of $50 \mathrm{ml}$ was applied equally to 36 pots (four genotypes $\times$ three date of sample collection $\times$ three replications of experiment). The last set of 36 pots was sprayed with clean water and treated as a control group (K). The pots with inoculated plants were covered with transparent plastic bags to maintain stable and high air humidity (>85\%). For the study of enzymes activity, leaf samples (about $0.2 \mathrm{~g}$ ) were collected on the third (T1), sixth (T2), and ninth (T3) day after inoculation, in three replications. The samples were placed in Eppendorf tubes $(2 \mathrm{ml})$ and deep-frozen $\left(-80^{\circ} \mathrm{C}\right)$ until analysis.

\section{Enzymatic assays}

The activity of $\beta$-glucosidase was determined based on Nichols et al. (1980). The leaves were ground in $0.1 \mathrm{M}$ phosphate buffer $\mathrm{pH} 7.0$ containing $0.5 \%$ of polyethylene glycol and $40 \mathrm{mg}$ of Polyclar AT. The supernatant obtained after centrifugation at $10,000 \mathrm{~g}$ for $15 \mathrm{~min}$ at $4{ }^{\circ} \mathrm{C}$ was used to determine enzyme activity. The mixture containing $0.3 \mathrm{ml}$ of extract and $0.3 \mathrm{ml}$ of 4-nitrophenyl- $b$-D-glucopyranoside as a substrate was incubated for $1 \mathrm{~h}$ at $30^{\circ} \mathrm{C}$. After the time, $0.9 \mathrm{ml}$ of $0.2 \mathrm{M} \mathrm{Na}_{2} \mathrm{CO}_{3}$ was added. The formation of $p$-nitrophenol (p-NP) was followed at $400 \mathrm{~nm}$. The activity was expressed as $\mu$ moles p-NP per mg protein (ActGluProt) and per mg of fresh matter (ActGluFM).

Guaiacol peroxidase measurement was based on the method of Hammerschmidt et al. (1982). Leaves were homogenized in $0.1 \mathrm{M} \mathrm{K}$-phosphate buffer $\mathrm{pH} 7.5$ and centrifuged at $10,000 \mathrm{~g}$ for $15 \mathrm{~min}$ at $4{ }^{\circ} \mathrm{C}$. Enzyme assays were prepared by adding $0.5 \mathrm{ml} 0.1 \mathrm{M} \mathrm{K}$-phosphate buffer $\mathrm{pH} 7.5$, $0.5 \mathrm{ml}$ extract, $0.5 \mathrm{ml} 3.4 \mathrm{mM}$ guaiacol, and $0.5 \mathrm{ml} \mathrm{H}_{2} \mathrm{O}_{2}$ to a glass cuvette. The absorbance at $480 \mathrm{~nm}$ was measured, and the guaiacol oxidation was expressed as nanokatals per mg protein (ActGPXProt) and per mg of fresh matter (ActGPXFM).

The determination of protein content in the leaves was made with the help of Bradford's (1976) and Kruger (2009) method. $2 \mathrm{ml}$ of a solution of Coomassie Brilliant Blue G-250 (CBB) in 85\% orthophosphoric acid was added to $100 \mu \mathrm{l}$ of a diluted extract. After $10 \mathrm{~min}$ the absorbance was measured at a wavelength of $595 \mathrm{~nm}$. Protein content was determined from a curve plotted for albumin.

\section{Statistical analysis}

The normality of the trait's distribution was tested using the Shapiro-Wilk's normality test (Shapiro and Wilk 1965). The three-way fixed model analysis of variance (ANOVA) was carried out to determine the effects of varieties of oilseed rape, pathogens, and term of sampling, as well as all interactions on the variability of observed traits (ActGluProt, ActGluFM, ActGPXProt, ActGPXFM). Estimations were also made by mean values, maximum and minimum values, and the coefficient of variation for the studied traits (Kozak et al. 2013). When critical differences were noted, multiple comparisons were carried out using the least significant differences (LSDs) for each trait. Based on this, homogeneous groups (not significantly different from one another) were determined for the analyzed traits. The relationships between observed traits were estimated using Pearson's correlation coefficients (Kozak et al. 2010) and presented in the scatterplot matrix. Data analysis was performed using the statistical package GenStat 17.

\section{Results}

\section{Disease symptoms}

In the conducted experiment at $\mathrm{T} 1$, all cultivars treated with A. brassicicola (A) on leaves exhibited first symptoms of infection-small, single dark spots. At T2, the spots were more numerous and also appeared on stalks; at T3, the disease symptoms were observed on about $80 \%$ of the plants. In all tested cultivars inoculated with A. alternata (E and $\mathrm{G})$ and also $C$. cladosporioides $(\mathrm{F})$ and $U$. chartarum $(\mathrm{D})$, the first disease symptoms appeared in T2. In T3, about $20 \%$ of plants presented symptoms of infection by A. alternata (E and G). In groups treated with A. brassicae (B) and A. alternata $(\mathrm{C})$ in $\mathrm{T} 3$, only scarcely single plants were infected.

\section{$\beta$-glucosidase activity/pathogens}

The highest mean $\beta$-glucosidase activity in samples collected in T1 was observed in plants inoculated with A. brassicicola (A) (mean $1.23 \mu$ moles p-NP/protein) (Table 1; Fig. 1). The mean values of enzyme activity for plants inoculated with other pathogens were similar (0.81-0.98). In T2, mean values of $\beta$-glucosidase activity in plants inoculated with four pathogens: A. brassicicola (A), A. alternata (E and G), and A. brassicae (B) were similar (Table 1; Fig. 1). They contained 1.32, 1.28, 1.21, and $1.19 \mu$ moles $\mathrm{p}-\mathrm{NP} /$ protein, respectively. The mean values of $\beta$-glucosidase activity for plants inoculated with other pathogens: A. alternata (C), $U$. chartarum (D), and C. cladosporioides $(\mathrm{F})$ were lower (0.99-1.99 $\mu$ moles p-NP/protein). In the samples, collected in T3, the mean $\beta$-glucosidase activity was highest in plants inoculated with $A$. brassicicola (A) $(1.66 \mu$ moles p-NP/mg protein) (Table 1; Fig. 1). The enzyme values measured in samples inoculated with other pathogens ranged from 1.40 to $1.11 \mu$ moles of $\mathrm{p}-\mathrm{NP} / \mathrm{mg}$ protein. The lowest enzyme activity value $(0.75 \mu$ moles $\mathrm{p}-\mathrm{NP} / \mathrm{mg}$ protein $)$ was reported in the control samples in all terms. 


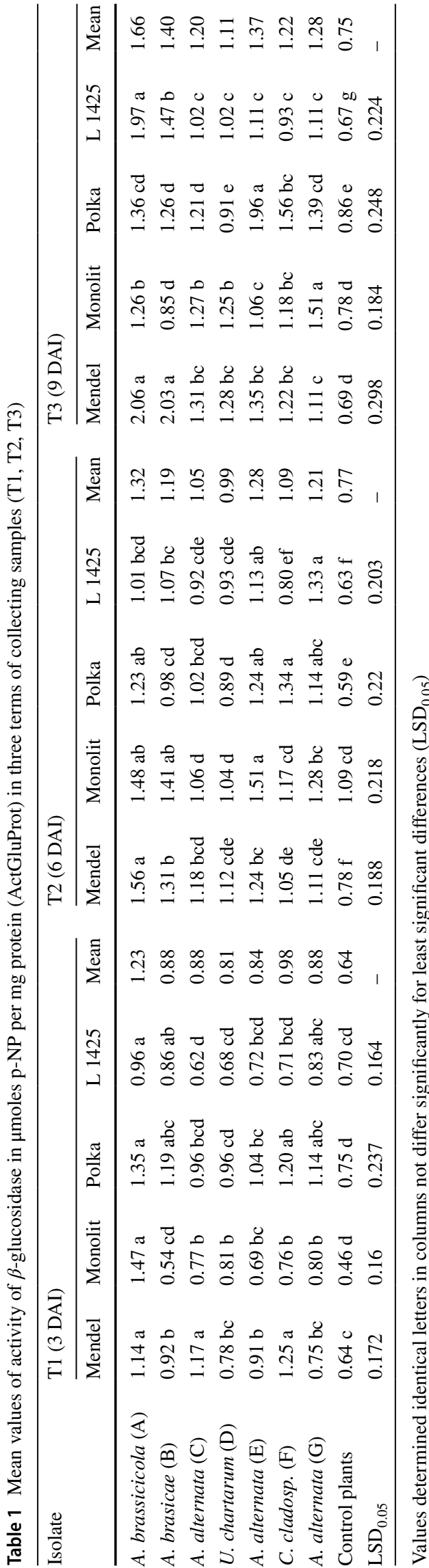

\section{$\beta$-glucosidase activity/rapeseed varieties}

In T1, the highest $\beta$-glucosidase activity was in Mendel variety inoculated with A. brassicicola (A), A. alternata (C), and $C$. cladosporioides $(\mathrm{F})$. The enzyme activity amounted to $1.14,1.17$, and $1.25 \mu$ moles $\mathrm{p}-\mathrm{NP} / \mathrm{mg}$ protein, respectively. In Monolit, Polka, and line 1425, the highest values of $\beta$-glucosidase activity were inducted by inoculation with $A$. brassicicola (A) and amounted to $1.47,1.35$ and $0.96 \mu$ moles in p-NP/mg protein (Table 1; Fig. 1). In T2, the highest $\beta$-glucosidase activity was observed in Mendel inoculated with A. brassicicola (A)-1.56; Monolit/A. alternata (E) - 1.51; Polka/C. cladosporioides $(\mathrm{F})-1.34$, and the yellow-seeded line/A. alternata $(\mathrm{G})-1.33 \mu$ moles $\mathrm{p}-\mathrm{NP} /$ mg protein (Table 1; Fig. 1). In T3 the highest increase in $\beta$-glucosidase activity was recorded after inoculation with A. brassicicola (A) in the Mendel variety 2.06; in Monolit with A. alternata $(\mathrm{G})-1.51$; in Polka with A. alternata (E) - 1.96, and in the yellow-seeded line A. brassicicola (A) $-1.97 \mu$ moles p-NP/mg protein (Table 1; Fig. 1). In all varieties and every term of samples collecting, the lowest value of $\beta$-glucosidase was recorded in the control groups (K) except the yellow-seeded line in samples tested three terms (Table 1; Fig. 1).

\section{GPX activity/pathogens}

The highest average GPX activity in T1 was observed in plants inoculated with A. brassicicola (A) (2.42 nanokatals/ mg protein) (Table 2; Fig. 2). The mean enzyme activity of plants inoculated with other pathogens varied from 1.34 to 1.98 nanokatals/mg protein. In T2, the highest mean values of GPX activity were recorded in plants inoculated with $A$. brassicicola (A) and A. alternata (G) (Table 2; Fig. 2). They amounted to 2.99 and 2.94 nanokatals/mg protein, respectively. Average peroxidase activity values for plants inoculated with other pathogens were similar (2.19-2.61) except combinations inoculated with $U$. chartarum (D), which was lower-1.84. In T3, the average activity of GPX was again the highest in plants inoculated with A. brassicicola (A) 5.38 and A. brassicae (B) 4.10 nanokatals/mg protein (Table 2; Fig. 2). The enzyme values determined in the rest of the samples ranged from 3.88 (A. alternata $\mathrm{G}$ ) to 2.65 (U. chartarum $\mathrm{D})$ nanokatals/mg protein.

\section{GPX activity/rapeseed varieties}

The highest GPX activity in T1 was observed in the Monolit variety after inoculation with $A$. brassicicola (A)3.30 nanokatals $/ \mathrm{mg}$ protein in the first term of collecting samples (Table 2; Fig. 2). In the Polka variety, the highest activity of GPX was measured after inoculation with C. cladosporioides $(\mathrm{F})-2.80$ and in the line 1425 after 

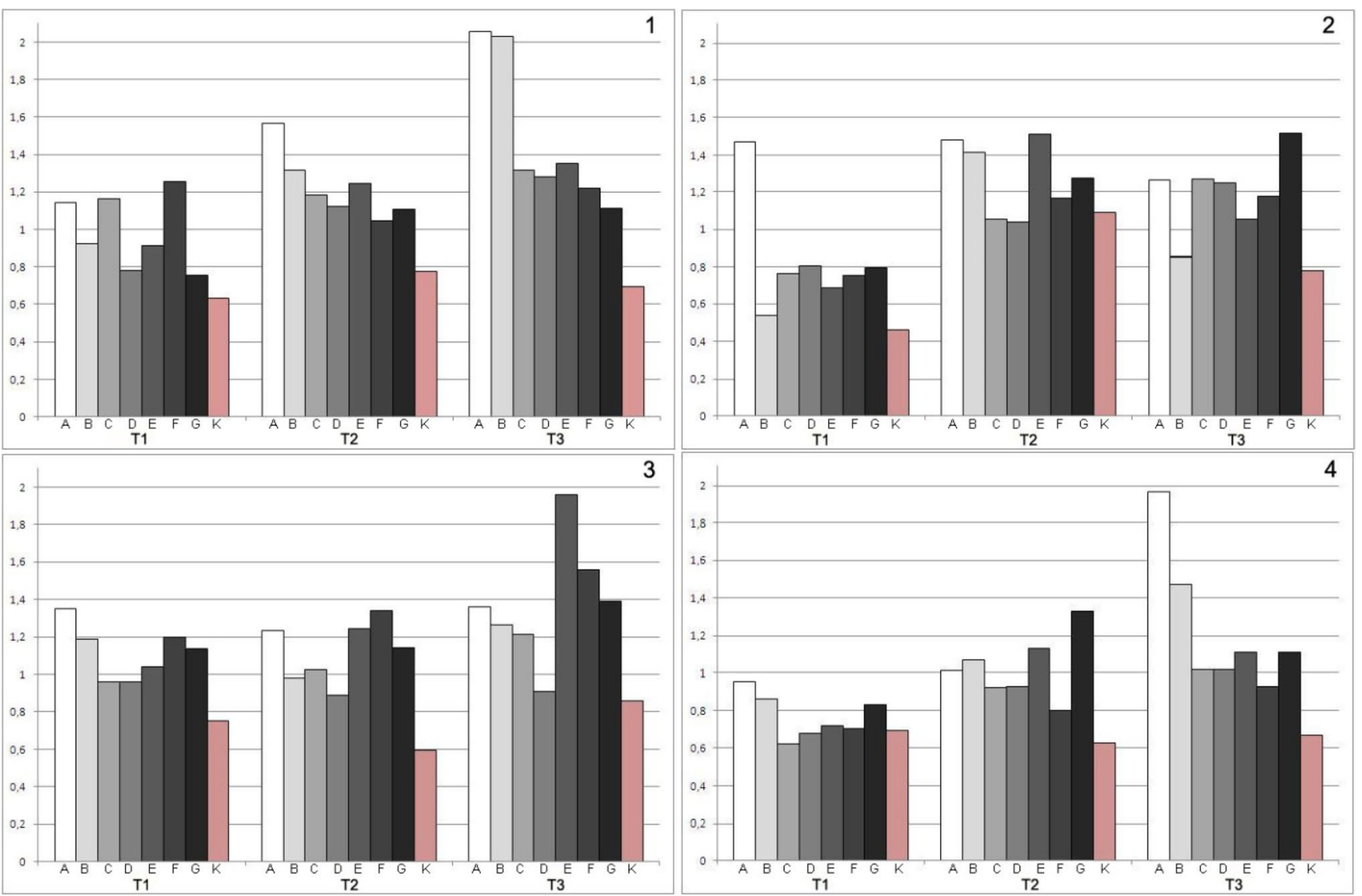

Fig. 1 Activity of $\beta$-glucosidase in $\mu$ moles p-NP per mg protein (ActGluProt). Isolates: A-A. brassicicola, $\mathrm{B}-A$. brasicae, $\mathrm{C}, \mathrm{E}, \mathrm{G}-A$. alternata, $\mathrm{D}-U$. chartarum, $\mathrm{F}-C$. cladosporioides, $\mathrm{K}$ - control

group. Genotypes of rapeseed: 1-Mendel, 2-Monolit, 3-Polka, 4-line L 1425), T1, T2, T3-terms of collecting samples

inoculation with $A$. alternata $(\mathrm{G})-2.47$ nanokatals $/ \mathrm{mg}$ protein (Table 2; Fig. 2). Inoculation of tested varieties with other pathogens caused variations in enzyme activity. In T2, the highest activity of GPX was observed in the Monolit and Polka samples inoculated with A. brassicicola (A) (Table 2; Fig. 2). These values amounted to 3.35 and 3.13 nanokatals/mg protein, respectively. In L 1425 plants, the highest activity of the enzyme was induced by inoculation with A. alternata $(\mathrm{G})-3.77$ nanokatals $/ \mathrm{mg}$ protein. In T3, the impact of different species of fungi on GPX activity was varied. The highest GPX activity was recorded for the Mendel cultivar (6.61) and L 1425 line (6.37 nanokatals/mg protein) after inoculation with $A$. brassicicola (A) (Table 2; Fig. 2). A high level of enzyme activity was observed for Polka as a result of inoculation with A. brassicicola (A)—4.25, and for a yellow-seeded line with A. brassicae (B)-4.64 nanokatals/mg protein.

The three-way analysis of variance also demonstrated the significance of the interaction: variety/pathogen, variety/day after infection (DAI), pathogen/DAI, and variety/ pathogen/DAI (Table 3 ). The activity of $\beta$-glucosidase and

GPX per the protein content and fresh matter were positively correlated at $P<0.001$ (Table 4).

\section{Discussion}

We noted that the varieties of oilseed rape, tested fungal species, and time of the plant material collection had significant $(P<0.001)$ effect on the activity of $\beta$-glucosidase and GPX per protein and fresh matter content comparing to the control group. However, the indication of one factor with the highest effect on the increase in the activity of the enzymes is difficult.

One of the most interesting factors affecting the increase in enzyme activity was the species of fungus used for inoculation. The highest average increase in $\beta$-glucosidase activity in all tested cultivars was caused by the most pathogenic species A. brassicicola. In the Mendel and L 1425 cultivars, it was particularly visible in T3 (2.02 and $1.97 \mu$ moles $\mathrm{p}-\mathrm{NP} / \mathrm{mg}$ protein, respectively) while in the Monolit cultivar in T1 and T2 (1.47 and $1.48 \mu$ moles $\mathrm{p}-\mathrm{NP} / \mathrm{mg}$ protein, 


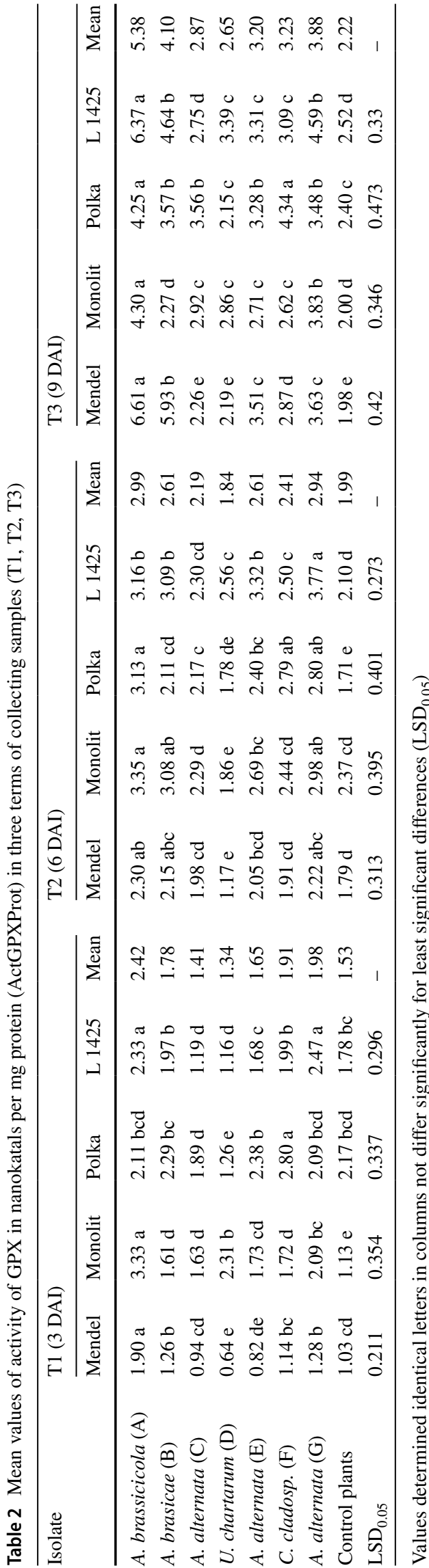

respectively). These results may indicate significant differences in $\beta$-gluosidase activity or time of enzymatic response for the pathogen infection between tested cultivars. Significant variations in phytochemical constituents among different rapeseed cultivars were previously reported by El-Beltagi et al. (2011). The highest GPX activity in all tested cultivars was also observed for A. brassicicola inoculation mainly in T3 (mean 5.38, 4.64 nanokatals/mg protein), but the activity increased gradually. Presumably, the GPX results were associated with the full development of the disease symptoms. Interesting observations relate to enzymatic changes occurring under the influence of $A$. alternata inoculation. A. alternata is the most cosmopolitan fungal species and causes diseases in over a hundred varieties of host plants. The species contains strains of varied pathogenicity and saprotrophs (Coates and Johnson 1997; Woudenberg et al. 2015). It can explain the obtained differences in enzyme activity. In the study, three genetically distinct $A$. alternata isolates were used. By analyzing average activity values, the isolate $\mathrm{C}$ of this pathogen induced a slightly weaker increase in $\beta$-glucosidase (except Mendel) (T1-1.41, T2-2.19, T3-2.87 $\mu$ moles $\mathrm{p}-\mathrm{NP} / \mathrm{mg}$ protein) and GPX activity $(\mathrm{T} 1-1.41, \mathrm{~T} 2-2.19, \mathrm{~T} 3-2.87)$ than $\mathrm{E}(\beta$-glucosidase: $\mathrm{T} 1-1.41, \mathrm{~T} 2-2.19, \mathrm{~T} 3-2.87 \mu$ moles $\mathrm{p}-\mathrm{NP} / \mathrm{mg}$ protein; GPX: T1-1.41, T2-2.19, T3-2.87 nanokatals/ $\mathrm{mg}$ protein) and $\mathrm{G}(\beta$-glucosidase: $\mathrm{T} 1-1.41, \mathrm{~T} 2-2.19$, T3-2.87 $\mu$ moles $\mathrm{p}-\mathrm{NP} / \mathrm{mg}$ protein; GPX: T1-1.41, $\mathrm{T} 2-2.19, \mathrm{~T} 3-2.87$ nanokatals/mg protein) isolates. Isolate $\mathrm{C}$ was less pathogenic then $\mathrm{E}$ and $\mathrm{G}$. In all tested cultivars inoculated with $A$. alternata ( $\mathrm{E}$ and $\mathrm{G}$ ) first disease symptoms appeared in $\mathrm{T} 2$ while in $\mathrm{T} 3$ isolate $\mathrm{C}$ infected only single plants. So, except for a few cases, the results correlate with enzyme activity. Variability of responses within one potato cultivar to different isolates of $A$. solani was described by Shahbazi et al. (2010). The authors indicate that the presence of genotypic diversity between isolates results in the diversity of the pathogen aggressiveness. Another main oilseed rape pathogen A. brassicae (B) is very changeable in induced enzyme activity. Attention is drawn only to a high level of $\beta$-glucosidase and GPX activity in Mendel variety in T3 $(2.02 \mu$ moles $\mathrm{p}-\mathrm{NP} / \mathrm{mg}$ protein and 5.93 nanokatals/ $\mathrm{mg}$ protein) and GPX in Polka in T3-3.57 nanokatals/ mg protein. Low pathogenicity of the strain A. brassicae can be explained by a successful response of plants to the pathogen, not enough time for the infection or influence of other factors. Typically, low $\beta$-glucosidase and GPX activity were observed by inoculation with less pathogenic species $U$. chartarum (D). Ambiguous results were obtained after inoculation with $C$. cladosporioides isolate (F). In some combinations, mainly in T1, the species caused a significant increase in $\beta$-glucosidase activity (Mendel T1, Polka T1, and T2). Additionally, C. cladosporioides isolate caused high GPX activity in the Polka variety in all three observation 


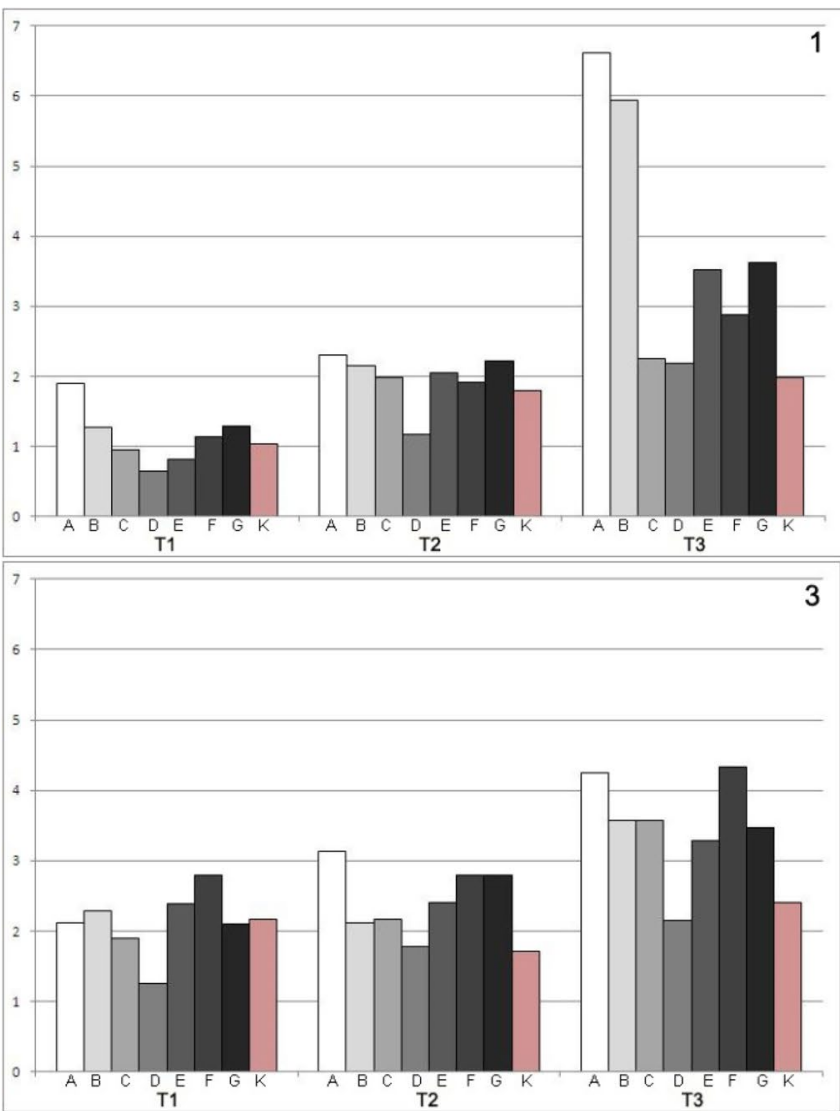

Fig. 2 Activity of guaiacol peroxidase in nanokatals per mg protein (ActGPXProt). Isolates: A-A. brassicicola, B-A. brasicae, C, E, $\mathrm{G}-$ A. alternata, $\mathrm{D}-U$. chartarum, $\mathrm{F}-\mathrm{C}$. cladosporioides, $\mathrm{K}-$

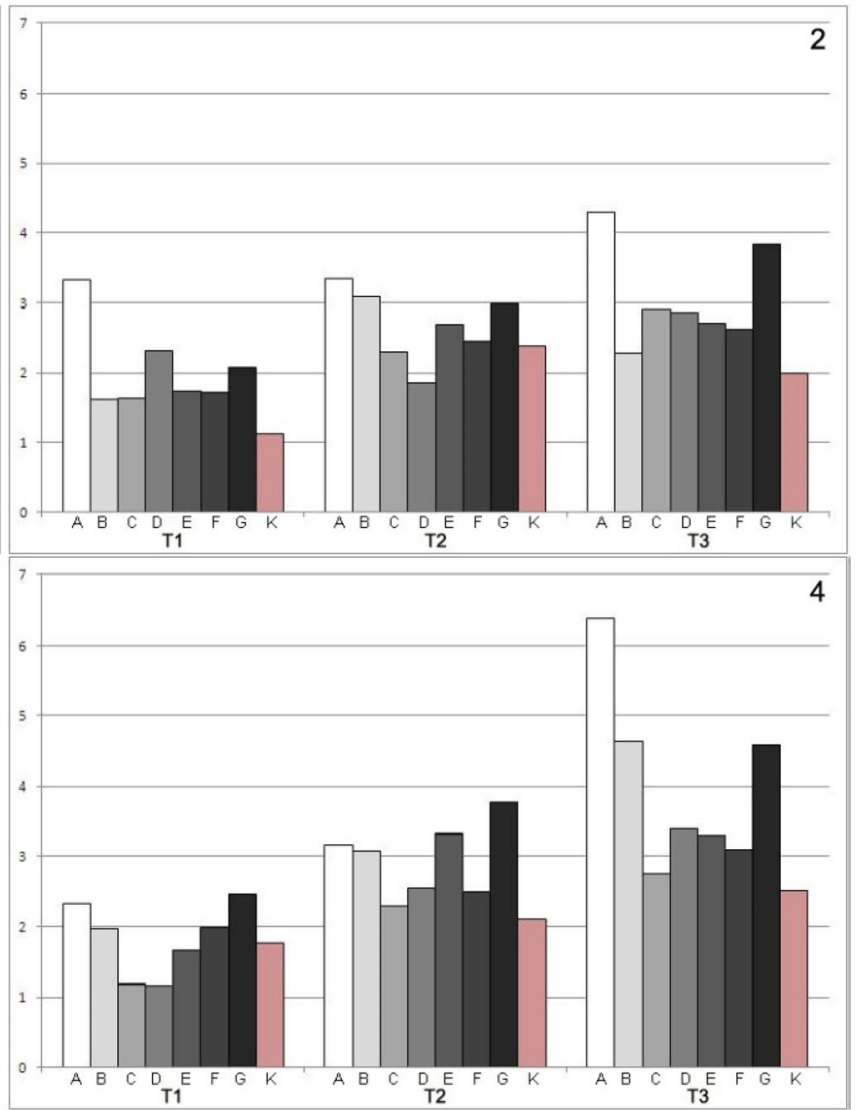

control group. Genotypes of rapeseed: 1-Mendel, 2-Monolit, 3Polka, 4-line L 1425), T1, T2, T3-terms of collecting samples
Table 3 Mean squares form analysis of variance (ANOVA) of observed activity of $\beta$-glucosidase and guaiacol peroxidase and their interaction for a variety of rapeseed, pathogen and the term of collecting samples

\begin{tabular}{|c|c|c|c|c|c|}
\hline Source of variation & d.f. & ActGluProt & ActGluFM & ActGPXProt & ActGPXFM \\
\hline Variety & 3 & $0.786 * * *$ & $38.741 * * *$ & $5.230 * * *$ & $872.726 * * *$ \\
\hline Pathogen & 7 & $1.185^{* * * *}$ & $14.473 * * *$ & $10.195 * * *$ & $125.228 * * *$ \\
\hline Term & 2 & $3.926 * * *$ & $36.969 * * *$ & $86.775 * * *$ & $2480.161 * * *$ \\
\hline Variety $\times$ Pathogen & 21 & $0.150 * * *$ & $4.805^{* * *}$ & $1.051 * * *$ & $19.734 * * *$ \\
\hline Variety $\times$ Term & 6 & $0.332 * * *$ & $30.364 * * *$ & $4.045 * * *$ & $88.875^{* * *}$ \\
\hline Patogen $\times$ Term & 16 & $0.098 * * *$ & $3.254 * * *$ & $1.979 * * *$ & $41.142 * * *$ \\
\hline Variety $\times$ Pathogen $\times$ Term & 42 & $0.126^{* * *}$ & $3.168 * * *$ & $0.772 * * *$ & $28.146^{* * *}$ \\
\hline Residual & 216 & 0.015 & 0.365 & 0.042 & $3.783 * * *$ \\
\hline
\end{tabular}

ActGluProt the activity of $\beta$-glucosidase in $\mu$ moles p-NP per mg protein, ActGluFM the activity of $\beta$-glucosidase in $\mu$ moles p-NP per mg of fresh matter, ActGPXProt the activity of guaiacol peroxidase in nanokatals per mg protein, ActGPXFM the activity of guaiacol peroxidase in nanokatals per mg of fresh matter, $n s$ not significant

$* * * P<0.00$ phases. This species is considered rather a saprotrophic, but in our study, it also inducted unexpected disease symptoms.

There is not enough information describing changes in the level of $\beta$-glucosidase and GPX activity in crop plants under the influence of pathogens. Significantly higher peroxidase activity in potato treated by $A$. solani isolates was correlated with resistant cultivar (Shahbazi et al. 2010). Rojas et al. (2018) suggest the transcriptional regulation of $\beta$-glucosidases and their possible impact in the defense mechanism against fungal Fusarium proliferatum infections in maize. Plants also respond to bacteria (Ralstonia 
Table 4 The Pearson correlation coefficients matrix for the observed activity of $\beta$-glucosidase and guaiacol peroxidase

ActGluProt ActGluFM ActGPXProt Act GPXFM

ActGluProt 1

ActGluFM $\quad 0.528 * * * \quad 1$

ActGPXProt $0.704 * * * \quad 0.207 * * * \quad 1$

Act GPXFM $\quad 0.353 * * * \quad 0.365 * * * \quad 0.733 * * * \quad 1$

ActGluProt the activity of $\beta$-glucosidase in $\mu$ moles $\mathrm{p}$-NP per mg protein, ActGluFM the activity of $\beta$-glucosidase in $\mu$ moles p-NP per mg of fresh matter, ActGPXProt the activity of guaiacol peroxidase in nanokatals per mg protein, ActGPXFM the activity of guaiacol peroxidase in nanokatals per $\mathrm{mg}$ of fresh matter, $n s$ not significant

$* * * P<0.00$

solanacearum) attacks by activating GPX and increase phenol content (Prakasha and Sharan 2016).

The differences in the activity of both enzymes were visible between the tested varieties. Significantly lower $\beta$-glucosidase activity due to inoculation with various pathogens was noted between the L 1425 line and others, especially Mendel. However, GPX activity was the opposite, the lowest activity was recorded in the Mendel variety, and the highest in the $\mathrm{L} 1425$ line. The results obtained may indicate that the tested varieties have different genetic characteristics that affect the response time to pathogen infection. The increase in GPX in plant tissues due to pathogen infection may be correlated with the level of plant resistance. Doullah et al. (2006) revealed different responses of different Brassica rapa genotypes to $A$. brassicicola infection, also under several factors-inoculum concentration, leaf stage, and incubation temperature. Differences in Fusarium head blight (FHB) resistance connected with enzymatic activity, among wheat cultivars were described by Spanic et al. (2020). The authors suggested that GPX activity, which is induced in response to pathogen invasion, might help the resistant wheat cultivar to limit infection by Fusarium species. Another study describes the response of different tomato genotypes to early blight disease caused by $A$. solani. The activation of defense responses-activities of catalase, peroxidase, polyphenol oxidase, and phenylalanine ammonia lyase was also more visible in resistant and moderately resistant tomato genotypes (Nafisa Shoaib et al. 2020).

Several factors determine a different level of disease resistance in rapeseed. Firstly, a presence of resistance genes and, secondly, the physical parameters of the plants which hinder pathogen access and penetration of plant tissues (El-Beltagi et al. 2011). The effectiveness of enzymatic pathways like $\beta$-glucosidase and GPX can contribute to maintaining plant health. The significant differences in $\beta$-glucosidase and GPX activity between tested varieties of rape in response to inoculation with different species of pathogenic fungi may indicate the diversity of the variety's capabilities to withstand the pathogen infection.

The significant differences in $\beta$-glucosidase and GPX activity between tested varieties of rape in response to inoculation with various species of pathogenic fungi may indicate the unequal capabilities of particular varieties to withstand the pathogen infection. The study also showed significant differences in the activity of the enzymes for the inoculation of strong and weak pathogenic fungi.

Author contribution statement KP designed the research and analyzed the experimental results. KP, AD, JW and AP carried out experiments in the greenhouse. MZ and MRZ carried out enzymatic tests. JB conducted a statistical analysis and assisted in analyzing the data and interpreting the results. KP, AD, JW, MRZ and JB wrote the article. KP and MRZ corrected the manuscript.

Open Access This article is licensed under a Creative Commons Attribution 4.0 International License, which permits use, sharing, adaptation, distribution and reproduction in any medium or format, as long as you give appropriate credit to the original author(s) and the source, provide a link to the Creative Commons licence, and indicate if changes were made. The images or other third party material in this article are included in the article's Creative Commons licence, unless indicated otherwise in a credit line to the material. If material is not included in the article's Creative Commons licence and your intended use is not permitted by statutory regulation or exceeds the permitted use, you will need to obtain permission directly from the copyright holder. To view a copy of this licence, visit http://creativecommons.org/licenses/by/4.0/.

\section{References}

Ashraf M, Ali Q (2008) Relative membrane permeability and activities of some antioxidant enzymes as the key determinants of salt tolerance in canola (Brassica napus L.). Environ Exp Bot 63:266-273. https://doi.org/10.1016/j.envexpbot.2007.11.008

Beckman CH (2000) Phenolic-storing cells: keys to programmed cell death and periderm formation in wilt disease resistance and in general defence responses in plants? Physiol Mol Plant Pathol 57(3):101-110. https://doi.org/10.1006/pmpp.2000.0287

Bradford MM (1976) A rapid and sensitive method for the quantitation of microgram quantities of protein utilizing the principle of protein-dye binding. Anal Biochem 72:248-254. https://doi. org/10.1016/0003-2697(76)90527-3

Coates L, Johnson G (1997) Postharvest diseases of fruit and vegetables. In: Brown JF, Ogle HJ (eds) Plant pathogens and plant diseases. Rockvale Publications, Armidale, pp 533-548

Doullah MAU, Meah MB, Okazaki K (2006) Development of an effective screening method for partial resistance to Alternaria brassicicola (dark leaf spot) in Brassica rapa. Eur J Plant Pathol 116:33-43. https://doi.org/10.1007/s10658-006-9035-2

El-Beltagi HS, Mohamed AA, Mekki B, El-Din B (2011) Differences in some constituents, enzymes activity and electrophoretic characterization of different rapeseed (Brassica napus L.) cultivars. Analele Universităţii din Oradea - Fascicula Biologie 18(1):45-52 
Halkier BA, Gershenzon J (2006) Biology and biotechnology of glucosinolates. Annu Rev Plant Biol 57:303-333. https://doi. org/10.1146/annurev.arplant.57.032905.105228

Hammerschmidt R, Nuckles EM, Kuć J (1982) Association of enhanced peroxidase activity with induced systemic resistance of cucumber to Colletotrichum lagenarium. Physiol Plant Pathol 20:73-82. https://doi.org/10.1016/0048-4059(82)90025-X

Heidari M (2010) Nucleic acid metabolism, proline concentration and antioxidants enzyme activity in canola (Brassica napus L.) under salinity stress. Agric Sci Chin 9(4):504-511. https://doi. org/10.1016/S1671-2927(09)60123-1

Jajor E, Korbas M (2012) Występowanie grzybów z rodzaju Alternaria w liściach i łuszczynach rzepaku z objawami czerni krzyżowych. Oilseed Crops 33(2):185-200

Ketudat Cairns JR, Esen A (2010) $\beta$-Glucosidases cell. Mol Life Sci 67:3389-3405. https://doi.org/10.1007/s00018-010-0399-2

Koch S, Dunker S, Kleinhenz B, Röhrig M, von Tiedemann A (2007) A crop loss-related forecasting model for sclerotinia stem rot in winter oilseed rape. Anal Theor Plant Pathol 97(9):1186-1194

Kozak M, Bocianowsk J, Sawkojć S, Wnuk A (2010) Call for more graphical elements in statistical teaching and consultancy. Biom Lett 47(1):57-68

Kozak M, Bocianowski J, Rybiński W (2013) Note on the use of coefficient of variation for data from agricultural factorial experiments. Bulg J Agric Sci 19(4):644-646

Kruger NJ (2009) The Bradford method for protein quantitation. In: Walker JM (ed) The protein protocols handbook. Springer Protocols Handbooks, Humana Press, Totowa

Kumar D, Maurya N, Kumar Y, Kumar A, Kumar K, Srivastava K, Chand G, Chanda K, Kumar S, Kumar R, Kumar A (2014) Alternaria blight of oilseed Brassicas: a comprehensive review. Afr J Microbiol Res 8:2816-2829. https://doi.org/10.5897/AJMR2 013.6434

Lee KH, Piao HL, Kim HY, Choi SM, Jiang F, Hartung W, Hwang I, Kwak JM, Lee IJ, Hwang I (2006) Activation of glucosidase via stress-induced polymerization rapidly increases active pools of abscisic acid. Cell 126(6):1109-1120. https://doi.org/10.1016/j. cell.2006.07.034

Logreico A, Moretti A, Solfrizzo M (2009) Alternaria toxins and plant diseases: an overviev of orgin, occurrence and risk. World Mycotoxin J 2(2):129-140. https://doi.org/10.3920/WMJ2009.1145

Meena PD, Awasthi RP, Chattopadhyay C, Kolte SJ, Kumar A (2010) Alternaria blight: a chronic disease in rapeseed-mustard. J Oilseed Brass 1:1-11

Moller BL (2010) Functional diversifications of cyanogenic glucosides. Curr Opin Plant Biol 13:338-347. https://doi.org/10.1016/j. pbi.2010.01.009

Morant AV, Jørgensen K, Jørgensen C, Paquette SM, Sánchez-Pérez $\mathrm{R}, \mathrm{M} \varnothing l$ ler BL, Bak S (2008) $\beta$-glucosidases as detonators of plant chemical defense. Phytochemistry 69:1795-1813. https://doi. org/10.1016/j.phytochem.2008.03.006

Nafisa Shoaib A, Iqbal J, Ali Khan K (2020) Evaluation of phenotypic, physiological and biochemical attributes connected with resistance in tomato against Alternaria solani. Acta Physiol Plant 42:88. https://doi.org/10.1007/s11738-020-03076-2

Nichols EJ, Beckman JM, Hadwiger LA (1980) Glycosidic enzyme activity in pea tissues and pea-Fusarium solani interaction. Plant Physiol 66:199-204. https://doi.org/10.1104/pp.66.2.199

Pandey VP, Awasthi M, Singh S, Tiwari S, Dwivedi UN (2017) A comprehensive review on function and application of plant peroxidases. Biochem Anal Biochem 6:308. https://doi. org/10.4172/2161-1009.1000308

Passardi F, Cosio C, Penel C, Dunad C (2005) Peroxidases have more functions than Swiss army knife. Plant Cell Rep 24:255-265. https ://doi.org/10.1007/s00299-005-0972-6

Perek A, Pieczul K, Dobrzycka A, Wolko J (2017) The influnce of alternaria black spot species on the oilseed rape infection development and intensity. Prog Plant Prot 57(2):109-114. https://doi. org/10.14199/ppp-2017-017

Prakasha A, Sharan U (2016) Biochemical and molecular variations of guaiacol peroxidase and total phenols in bacterial wilt pathogenesis of Solanum melongena. Biochem Anal Biochem 5:3. https:// doi.org/10.4172/2161-1009.1000292

Prasannath K (2017) Plant defence-related enzymes against pathogens: a review. AGRIEAST J Agric Sci 11(1):38-48. https://doi. org/10.4038/agrieast.v11i1.33

Rask L, Andreasson E, Ekbom B, Eriksson S, Pontoppidan B, Meijer J (2000) Myrosinase: gene family evolution and herbivore defense in Brassicaceae. Plant Mol Biol 42:93-113

Rojas M, Ascencio F, Tiessen A, Arce-Montoya M, Gómez-Anduro G (2018) Infection of maize inbred B73 by Ustilago maydis and Fusarium proliferatum triggers differential expression of the $\beta$-glucosidase genes. Physiol Mol Plant Pathol 104:127-134. https ://doi.org/10.1016/j.pmpp.2018.09.007

Shahbazi H, Aminian H, Sahebani N, Halterman DA (2010) Biochemical evaluation of resistance responses of potato to different isolates of Alternaria solani. Phytopathology 100(5):454-459. https ://doi.org/10.1094/PHYTO-100-5-0454

Shapiro SS, Wilk MB (1965) An analysis of variance test for normality (complete samples). Biometrika 52:591-611

Sharma P, Jha AB, Dubey RS, Pessarakli M (2012) Reactive oxygen species, oxidative damage, and antioxidative defense mechanism in plants under stressful conditions. J Bot 2012:1-26. https://doi. org $/ 10.1155 / 2012 / 217037$

Sherameti I, Venus Y, Drzewiecki C, Tripathi S, Mohan Dan V, Nitz I, Varma A, Grundler FM, Oelmu R (2008) PYK10, a $\beta$-glucosidase located in the endoplasmatic reticulum, is crucial for the beneficial interaction between Arabidopsis thaliana and the endophytic fungus Piriformospora indica. Plant J 54:428-439. https://doi. org/10.1111/j.1365-313X.2008.03424.x

Simmons EG (2007) Alternaria: an identification manual. CBS Biodivers Ser 6:1-775

Spanic V, Zdunić Z, Drezner G, Viljevac Vuletić M (2020) Differences in physiological traits at the initial stage of Fusarium head blight infection in wheat. Biol Plant 64:174-181. https://doi. org/10.32615/bp.2020.014

Vance CP, Kirk TK (1980) Lignification as a mechanism of disease resistance. Annu Rev Phytopathol 18:259-288. https://doi. org/10.1146/annurev.py.18.090180.001355

Woudenberg JH, Seidl MF, Groenewald JZ, de Vries M, Stielow B, Thomma BP, Crous PW (2015) Alternaria section Alternaria: species, formae speciales or pathotypes? Stud Mycol 82:1-21. https://doi.org/10.1016/j.simyco.2015.07.001

Publisher's Note Springer Nature remains neutral with regard to jurisdictional claims in published maps and institutional affiliations. 